\title{
VALIDATION OF THE SERVICEABILITY OF THE MANUFACTURING SYSTEM USING SIMULATION
}

\begin{abstract}
This article discusses the creation and use of known algorithms in production that uses a flow-shop system to monitor and verify its operability. It also describes the input data, which must be further opportunities for decision entered into the system. In the next section are described in detail the different parts of this procedure. Than it describes the sequential problems that are not yet at a practical level, few addressed, but thus methods shorten the processing time. The conclusion focuses on the validation of the serviceability of the manufacturing system using knowledge mentioned and their embedding and verification by simulation.
\end{abstract}

\section{Key Words}

Flow-shop system, algorithm, sequential problems, simulation model, serviceability, wastage rate

\section{Ivan Lazár, Jozef Husár}

Technical University in Kosice ivan.lazar@tuke.sk

\section{ARTICLE INFO}

Article type

Full research paper

doi: 10.7160/eriesj.2012.050407

Article history

Received: October 18, 2012

Received in revised form: December 8, 2012

Accepted: December 15, 2012

Available on-line: December 30, 2012

Lazár, I., Husár, J. (2012) "Validation of the Serviceability of the Manufacturing System Using Simulation", Journal on Efficiency and Responsibility in Education and Science, Vol. 5, No. 4, pp. 252-261, ISSN 1803-1617, [on-line] www.eriesjournal.com/_papers/article_192.pdf 


\section{Introduction}

With the advent of just-in-time manufacturing philosophy which maintains a limited in-process inventory, the flowshop scheduling problem with minimum make-span and optimization approaches to minimize manufacturing cost started to be intensively studied (Modrak and Moskvich, 2011). Flow-shop scheduling problems present an important class of sequencing problems in the field of production planning. Solving this problem means finding a permutation of jobs to be processed sequentially on a number of machines under the restriction that the processing of each job has to be with respect to the objective of minimizing the total processing time i.e. flow-time (Sule, 1982). The permutation flow-shop scheduling problem (PFSP) is often designed by the symbols $n|m| P \mid C_{\text {max }^{\prime}}$ where $n$ jobs have to be processed on $m$ machines in the same order. The processing of each job on each machine is an operation which requires the exclusive use of the machine for an uninterrupted duration called the processing time. " $P$ " indicates that only permutation schedules are considered, where the order in which each machine processes the jobs is identical for all machines. Hence a schedule is uniquely represented by a permutation of jobs. The common objective is to find a schedule that minimizes the makespan $C_{\max }$ the time at which the last job is completed on the last machine. In a statistical review of flow-shop scheduling research, concluded that there is lack of relevance to practice for the overall majority of research in this field. They emphasize "that flow-shop scheduling research is in dire need of paradigm shift to enhance its probability of ever becoming a tool for the practice (Bucki and Chramcov, 2011).

Complexity theory provides a mathematical framework, in which computational problems are studied so that they can be classified as "easy" or "hard" (Brucker, 1998). For the pure flow shop problem, there are generally $(n !)^{m}$ different sequencing alternatives. However, for the PFSP the search space is reduced to $n$ ! because it considers the same order of processing all the jobs in all machines. Consequentially, the $n$-job $m$-machine PFSPs belong to the class of NP-hard problems (Lenstra, 1997) Thus, in a PFSP, the computational requirements for obtaining an optimal solution increase exponentially as problem size increases. Nevertheless, it is well-known that the case of the PFSP composed of two machines (F2 I|Cmax), could be easily solved using Johnson's rule which generates an optimal schedule in $O\left(n^{*} \log (n)\right)$ time (Johnson, 1954 and Carlier, 1996). However, for $m \geq 3$, the problem is shown to be strongly NPhard (Garey et. al., 1976).

Complexity of manufacturing system, wastage rate and serviceability of this system are some of the most important concepts in theory of production systems in practical solutions as well as in theoretical modeling. To create a universal tool for Flow-shop production system is necessary to take into account several basic input parameters. In order to achieve the required parameters, it is necessary to maintaining a chronology for the optimization, and the next steps:

- analyze the raw data and analyze the production program (ABC analysis and PQ diagrams),

- perform a detailed analysis of the current layout,

- calculate the capacity of the functional elements of production systems,

- apply the segmentation of production - design of groups of components, or choose representatives (PFA analysis, cluster analysis, ROCA, DCA algorithm and others),

- propose an alternative solution,

- select a suitable simulation program, 
- verify the simulation model with number of changes and input values,

- verify the operability of system.

\section{General algorithm development of production lines with the principles of flow - shop}

Procedure written or graphic, which describes the same problem solving we can simply call the algorithm. Each algorithm is composed of individual steps that lead either to the next step or gradually returns to predetermined level solutions. (Anu, 1997)

\section{Materials and Methods}

Simulation is becoming increasingly used method for testing and monitoring of various systems and phenomena. Simulation can be used to investigate the causes of various disorders and can be used for the prevention of these disorders and accidents.

This article is divided in several parts. In first part we have created a unique graphic algorithm, which serves as a map for designing and creating a simulation model (created to verify operability of PS (PS-production system)). This simulation model can be defined in several ways:

based on experience,

- based on real PS,

- based on mathematical model

- based on pervious simulation with the change of domain. (Knapcikova et al,2011)

In next section we conceived the design organization chart of the manufacturing process. This chart is divided in 5 phases (from input data and quantities to profit and cost). Third part consists of

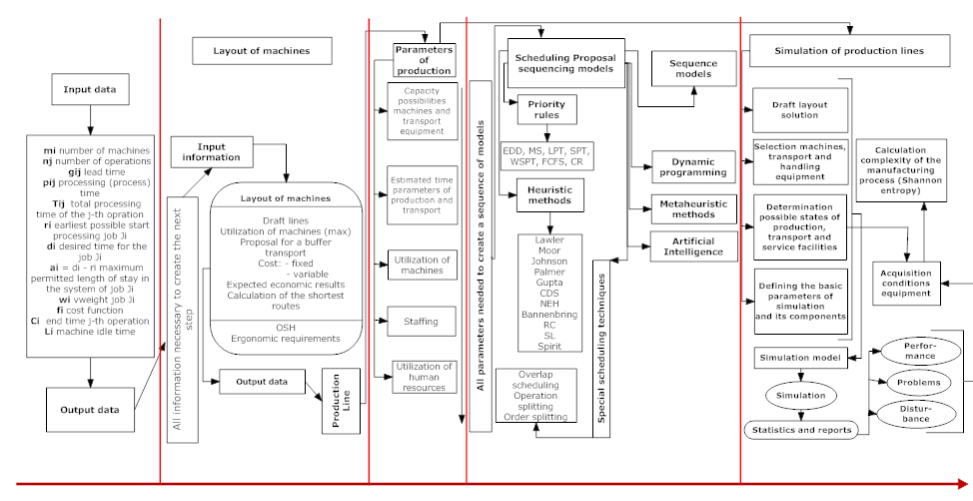

Figure 1: Flow diagram of simulation model (Gupta, 1971), (Husár and Lazár, 2011).

\section{Input parameters}

- $w_{i}$ weight tasks $J_{i^{\prime}}$. It expresses its relative importance,

- $f_{i}$ cost function - non-decreasing real function, that metering costs $f_{i}(t)$, paid to, the role $J_{i}$ was completed in time $t$. In general $g_{i^{\prime}} p_{i^{\prime}}$; or. $p_{i j}$ and $w_{i}$ are integers,

- $C_{i}$ end time $j$-th operation on the $i$-th machine (possible start $j+1$-th operation on the $i$-th machine),

- $L_{i}$ downtime of the machine to start j+1-th operation

- $m_{i}$ number of machines $m_{i}=\left\{\mathrm{S}_{1}, \mathrm{~S}_{2}, \mathrm{~S}_{3^{\prime}}, \ldots, \mathrm{S}_{\mathrm{i}}\right\}$ or $\left\{\mathrm{M}_{1^{\prime}}, \mathrm{M}_{2}, \mathrm{M}_{3^{\prime}}\right.$ $\left.\ldots, M_{i}\right\}$, where $j=1,2, \ldots, n$ and $i=1,2, \ldots, m$

- $n_{j}$ number of operations $n_{j}=\left\{\mathrm{O}_{1^{\prime}} \mathrm{O}_{2^{\prime}} \mathrm{O}_{3^{\prime}} \ldots, \mathrm{O}_{\mathrm{i}}\right\}$ or $\left\{\mathrm{J}_{1^{\prime}} \mathrm{J}_{2^{\prime}} \mathrm{J}_{3^{\prime}}\right.$ $\left.\ldots, \mathrm{J}_{\mathrm{i}}\right\}$,

- $g_{i j}$ lead time for processing $j$-th operation on the $i$-th machine,

- $p_{i j}$ processing (process) time $j$-th operation on the $i$-th machine, 
- $T_{i j}$ total processing time $j$-th operation on the $i$-th machine,

- $r_{i}$ earliest possible start of processing tasks $J_{i}$. This statement can be viewed as a time entry task $J_{i}$ to system (release date),

- $d_{i}$ required time of completion of tasks $J_{i^{\prime}}$

- $a_{i}=d_{i}-r_{i}$ maximum permissible length of stay roles $J_{i}$ in system. (Lazár and Husár, 2011)

The result of projecting the spatial structure of the production process is plant layout and of workplaces, so the actual technological project. A simplified diagram (model) design organization of the manufacturing process is on figure 2 . The design here is a gradual work ongoing in phases.

\section{Steps in the simulation model}

The application of simulation involves specific steps in order for the simulation study to be successful. Regardless of the type of problem and the objective of the study, the process by which the simulation is performed remains constant. The following briefly describes the basic steps in the simulation process by (Husár and Lazár, 2011);

\section{STEP 1 Identify and formulate the problem.}

Enumerate problems with an existing system. Produce requirements for proposed system. Select the bounds of the system, the problem or a part thereof, to be studied. Define overall objective of the study and a few specific issues to be addressed.

\section{Step 2 Collect and process real system data.}

Collect data on system specifications, input variables, as well as performance of the existing system.

\section{Step 3 Perform verification and validation on the model.}

Develop schematics and network diagrams of the system and translate these conceptual models to simulation software acceptable form. Verify that the simulation model executes as intended. Compare the model's performance under known conditions with the performance of the real system. The aim of verification and validation is to ensure that the model is sufficiently accurate.

\section{Step 4 Document model for future use.}

Document objectives, assumptions and input variables in detail. Variables of a simulation model so that we may observe and identify the reasons for changes in the performance measures.

\section{Step 5 Select appropriate experimental design.}

Select a performance measure, a few input variables that are likely to influence it, and the levels of each input variable. Document the experimental design.

\section{Step 6 Establish experimental conditions for runs.}

Simulation experiment is a test or a series of test in which meaningful changes are made to the input variables of a simulation model. First, address the question of obtaining accurate information and the most information from each run. Then, determine if the system is stationary (performance measure does not change over time) or non-stationary (performance measure changes over time).

\section{Step 7 Perform simulation run.}

The main model and the other scenarios based on experiment designs are run to get the output and results to compare. 
Simulation needs to be run with many replications which is, replication is defined as executing the same model a numbers of times, but with different random number in each runs.

\section{Step 8 Implement the model in real setting.}

The original system and the modification described were studied.

\section{Step 9 Recommend further course of action.}

This may include further experiments to increase the precision and reduce the bias of estimators, to perform sensitivity analyses, etc. (Dlouhy, 2007)

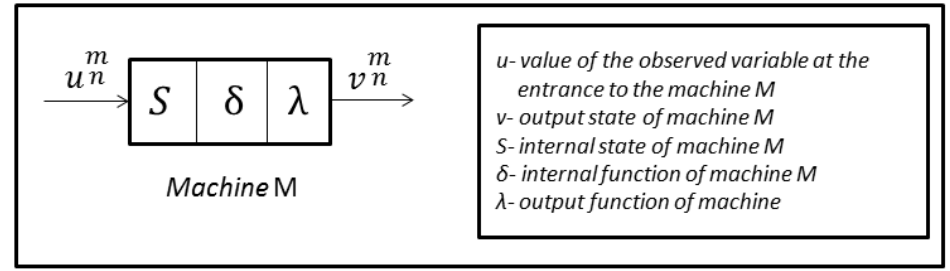

Figure 2 Mathematical model of one machine production

The simulation programs allow us to predict a variety of conflict situations, that would businesses have a lot of money and thanks to the fact that the entire of production process for our simulation program takes only a few minutes. With the program can produce a variety of statistics, graphs and reports that are used to detect bottlenecks and places, where the likelihood of malfunction of the real process.

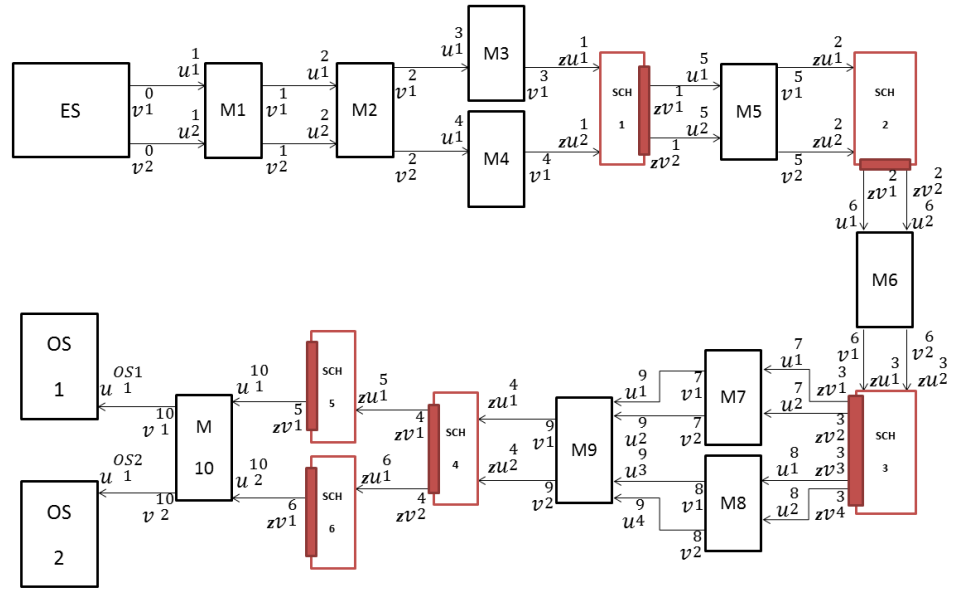

Figure 3: Mathematical model of simulation I.

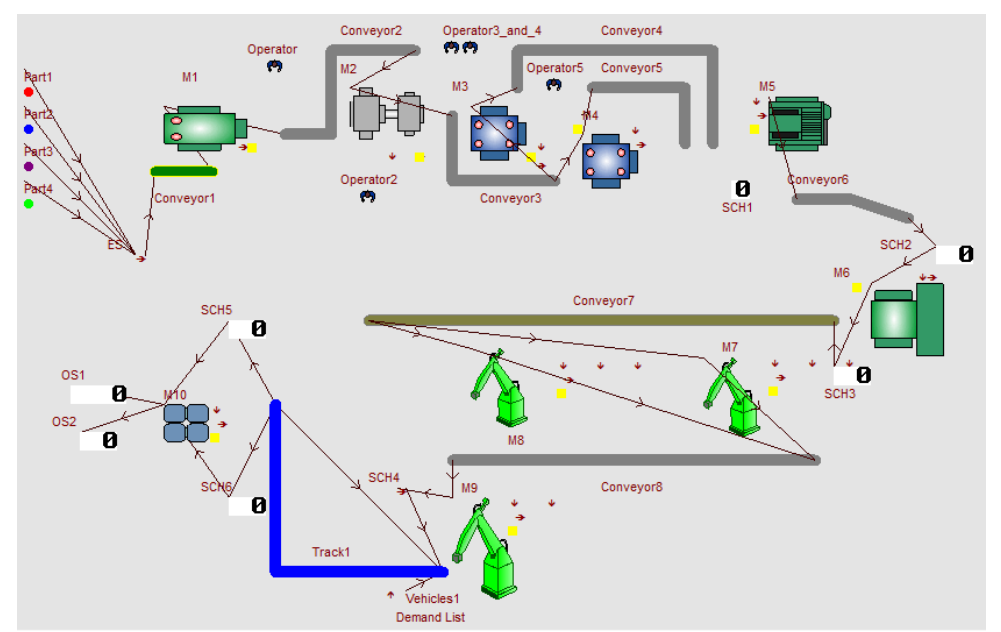

Figure 4: Simulation I field in Witness. 
Figures 3 and 4 graphically illustrate the simulation I on Witness software. Figure 3 shows a mathematical model. This model describes all inputs and outputs that operate on different machines or buffers. Figure 4 describes the simulation field of Witness, which illustrates mentioned mathematical model. This simulation focuses on the states of machines and the failure rate after 8 hours shift. Graphical representation of states of machines, conveyor and parts are on the Figure 7 to Figure 12 below.

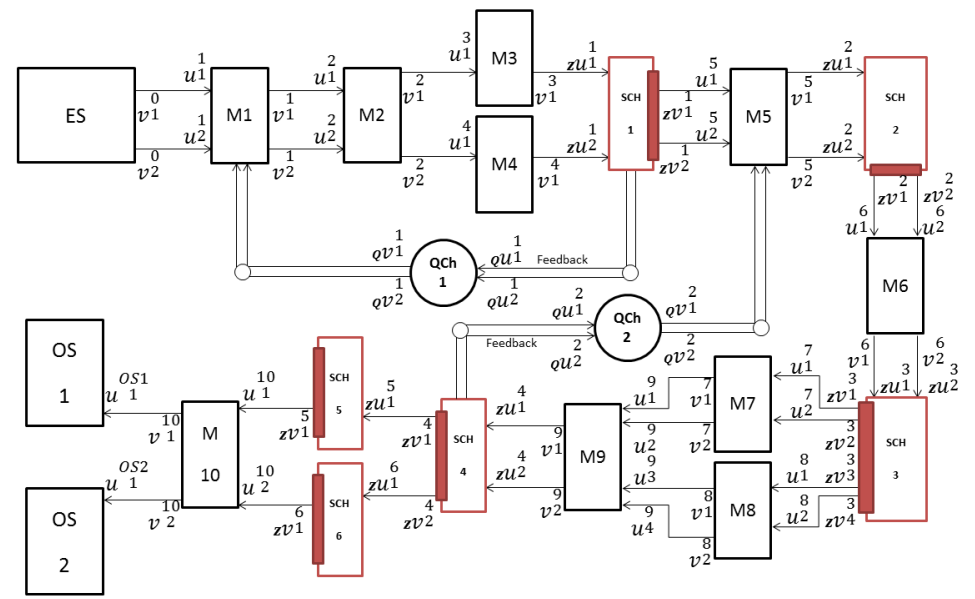

Figure 5: Mathematical model of simulation II.

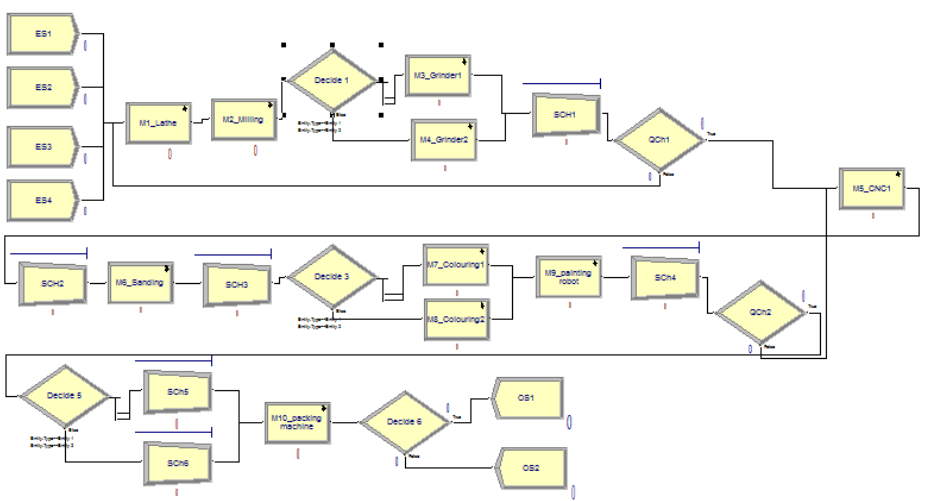

Figure 6: Simulation II field in ARENA.

\section{Results}

Figures 5 and 6 graphically illustrate the simulation II on Arena software. Figure 5 shows a mathematical model. This model describes all inputs and outputs that operate on different machines or buffers. Figure 6 describes the simulation field of Arena, which illustrates mentioned mathematical model. This simulation focuses on the error rate during 8 hours shift.

$\begin{aligned} \text { State of M1 } & \begin{array}{c}\text { Unfastening } \\ \text { Setup }\end{array} \\ \text { State of M2 } & \text { Grinding } \\ \text { State of M3 } & \text { Unfastening } \\ \text { State_of_M4 } & \text { Machining } \\ \text { State of M5 } & \text { Loading } \\ \text { State of M6 } & \text { Colour insert } \\ \text { State of M7 } & \text { Dry Cleaning } \\ \text { State of M8 } & \text { Painting } \\ \text { State of M9 } & \text { Transfer to storage } \\ \text { State_of_M10 } & \end{aligned}$

Figure 7: Running machines states. 


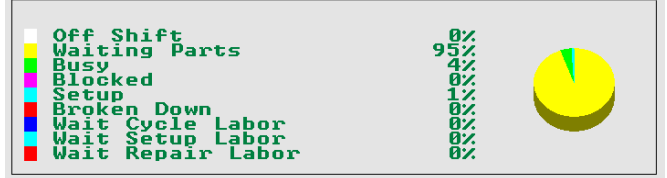

Figure 8: Process Performance Pie Chart after one part finishing.

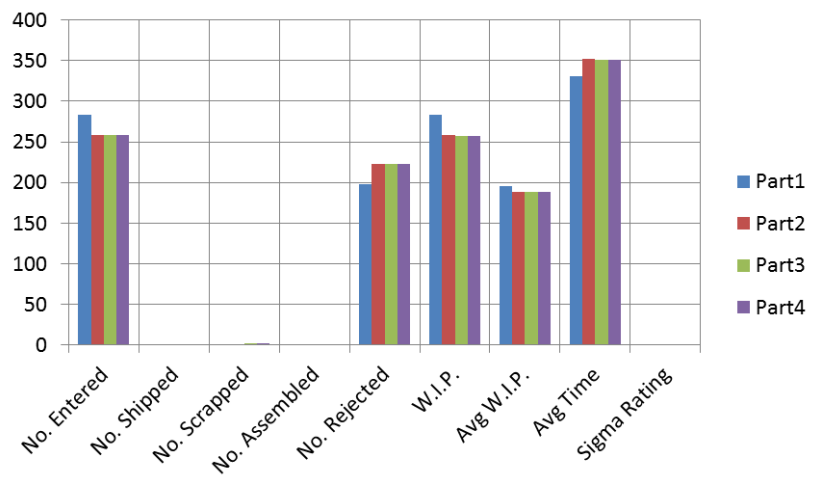

Figure 9: Part Statistics. Report by On Shift Time.

\begin{tabular}{|l|c|c|c|c|}
\hline Name & Part 1 & Part 2 & Part 3 & Part 3 \\
\hline No. Entered & 283 & 258 & 258 & 258 \\
\hline No. Shipped & 0 & 0 & 0 & 0 \\
\hline No. Scrapped & 0 & 0 & 1 & 1 \\
\hline No. Assembled & 0 & 0 & 0 & 0 \\
\hline No. Rejected & 198 & 223 & 223 & 223 \\
\hline W.I.P. & 283 & 258 & 257 & 257 \\
\hline Avg W.I.P. & 195.17 & 188.98 & 188.44 & 188.40 \\
\hline Avg Time & 331.26 & 351.83 & 350.83 & 350.75 \\
\hline Sigma Rating & 0.00 & 0.00 & 0.00 & 0.00 \\
\hline
\end{tabular}

Table 1: Part statistics after 8 hours shift.

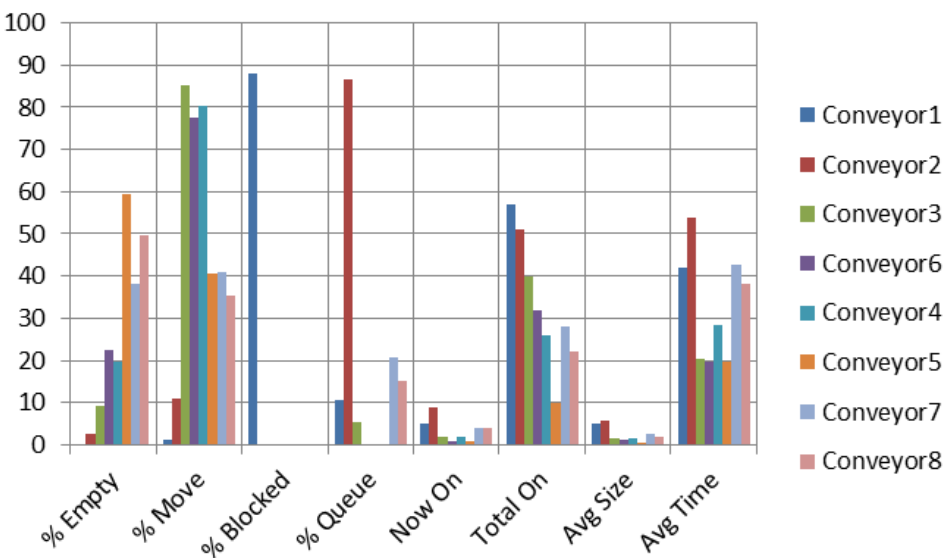

Figure 10: Conveyor Statistics. Report by On Shift Time.

\begin{tabular}{|c|c|c|c|c|c|c|c|c|}
\hline Name & $\begin{array}{c}\% \\
\text { Empty }\end{array}$ & $\begin{array}{c}\% \\
\text { Move }\end{array}$ & $\begin{array}{c}\% \\
\text { Blocked }\end{array}$ & $\begin{array}{c}\% \\
\text { Queue }\end{array}$ & $\begin{array}{c}\text { Now } \\
\text { On }\end{array}$ & $\begin{array}{c}\text { Total } \\
\text { On }\end{array}$ & $\begin{array}{c}\text { Avg } \\
\text { Size }\end{array}$ & $\begin{array}{c}\text { Avg } \\
\text { Time }\end{array}$ \\
\hline Conveyor1 & 0.00 & 1.25 & 88.13 & 10.62 & 5 & 57 & 4.98 & 41.96 \\
\hline Conveyor2 & 2.50 & 10.99 & 0.00 & 86.51 & 9 & 51 & 5.71 & 53.82 \\
\hline Conveyor3 & 9.37 & 85.22 & 0.00 & 5.41 & 2 & 40 & 1.67 & 20.4 \\
\hline Conveyor6 & 22.48 & 77.52 & 0.00 & 0.00 & 1 & 32 & 1.30 & 19.59 \\
\hline Conveyor4 & 19.78 & 80.22 & 0.00 & 0.00 & 2 & 26 & 1.53 & 28.24 \\
\hline Conveyor5 & 59.33 & 40.67 & 0.00 & 0.00 & 1 & 10 & 0.41 & 19.53 \\
\hline Conveyor7 & 38.31 & 40.87 & 0.00 & 20.82 & 4 & 28 & 2.48 & 42.51 \\
\hline Conveyor8 & 49.55 & 35.46 & 0.00 & 14.99 & 4 & 22 & 1.75 & 38.29 \\
\hline
\end{tabular}

Table 2: Conveyor statistics after 8 hours shift. 


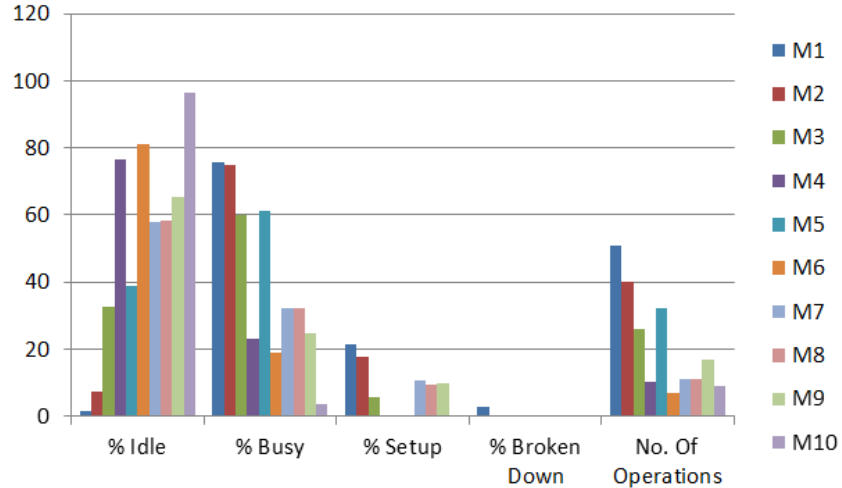

Figure 11: Machine Statistics. Report by On Shift Time.

The figure shows that the most broken down machine was machine M1 than machines M2 and M3. Most idle machine was machine M10 and it was more than $96 \%$ and on the other side the less idle machine was M1 it was less than $2 \%$.

\begin{tabular}{|c|c|c|c|c|c|}
\hline Name & $\begin{array}{c}\% \\
\text { Idle }\end{array}$ & $\%$ Busy & $\%$ Setup & $\begin{array}{c}\% \text { Broken } \\
\text { Down }\end{array}$ & $\begin{array}{c}\text { No. Of } \\
\text { Operations }\end{array}$ \\
\hline M1 & 1.4 & 75.64 & 21.24 & 2.8 & 51 \\
\hline M2 & 7.49 & 75.02 & 17.7 & 0.42 & 40 \\
\hline M3 & 32.48 & 60.03 & 5.62 & 0.42 & 26 \\
\hline M4 & 76.68 & 22.90 & 0.00 & 0.00 & 10 \\
\hline M5 & 38.83 & 61.17 & 0.00 & 0.00 & 32 \\
\hline M6 & 81.05 & 18.95 & 0.00 & 0.00 & 7 \\
\hline M7 & 57.88 & 32.06 & 10.6 & 0.00 & 11 \\
\hline M8 & 58.50 & 32.06 & 9.44 & 0.00 & 11 \\
\hline M9 & 65.37 & 24.84 & 9.78 & 0.00 & 17 \\
\hline M10 & 96.25 & 3.75 & 0.00 & 0.00 & 9 \\
\hline
\end{tabular}

Table 3: Machine statistics after 8 hours shift.
On Figure 12 are shown states of machines M1 to M10 every hour during 8 hours shift on the percentage basis. We can see that the machines were the most time in state BUSSY. The average value of the state was $74,625 \%$.

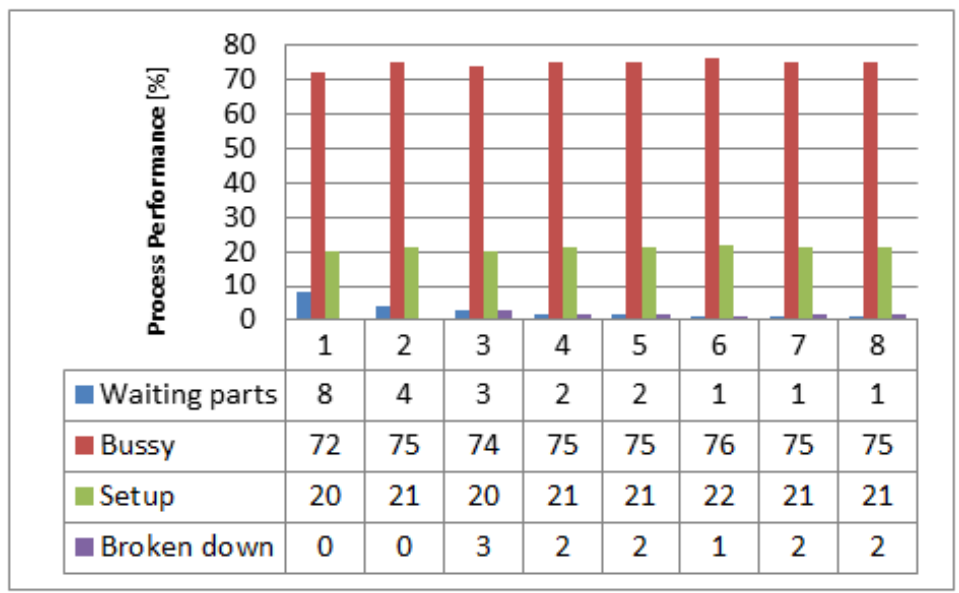

Figure 12: Process Performance on a percentage basis

Nine parts were completed after 8-hour shift. Seven finished parts were waiting to be wrapped on machine M10. Twentyeight parts were waiting to be coloured and painted. Time after passing four parts ( 1 part from 1 type) was $620 \mathrm{~min}$. From this time was less than $20 \%$ machining time and more than $80 \%$ shipping time. In the next steps we describe the simulation II in the ARENA. 


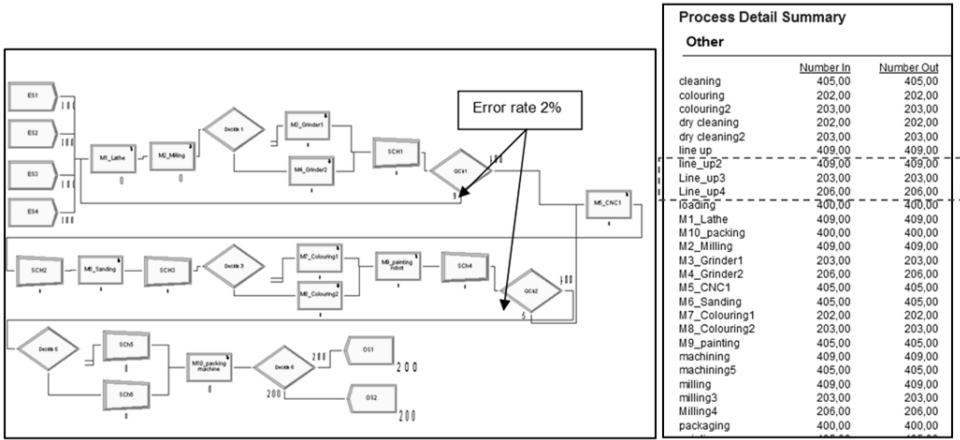

Figure 13: Results of errors rate $2 \%$ for 100 pieces of each component

In Figure 13 we can see a simulation of the manufacturing process in the ARENA programme. The simulation assign to the insertion of position to control on QCh1 QCh2 which is set to $2 \%$ error rate. As input data were put to the simulation 4 units of 100 pieces, where the error rate of $2 \%$ on the QCh1were 9 error rate and on the QCh2 were 5 error rate. After running the simulation it is possible to generate reports in time and number form, rate units, utilization of machines, input and output units in machines. From the machine Line_up 3 (on the left side) is seen that the error was 9 and in entities Nr. 1, 2 was 3 errors rate. From a machine Line_up fourth arising that in entities 3 and 4 were 6 errors.
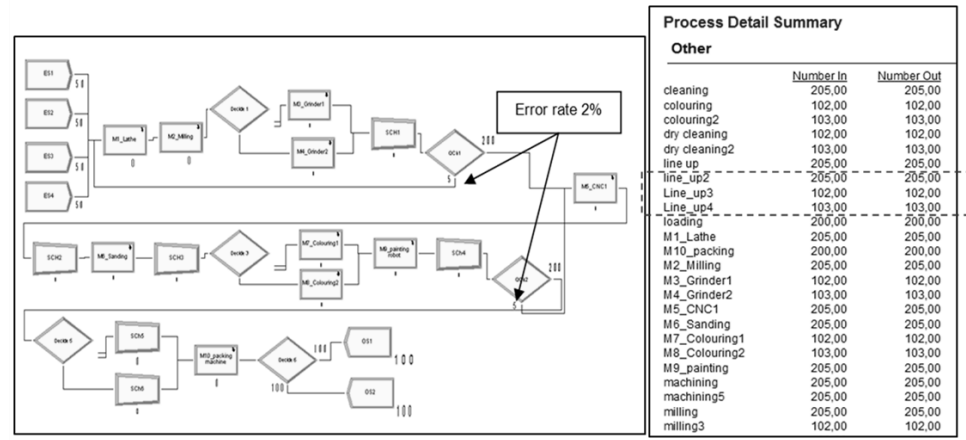

Figure 14: Results of errors rate $2 \%$ for 50 pieces of each component

In Figure 14 is presented the simulation 4 units of 50 pieces with $2 \%$ error rate. On the position QCh1 were 5 errors units and on the position QCh2 was errors units. On the left side (Machine Line_up 3) is seen that the error was 5 errors and entities Nr.1, 2 was incorrect 2 entities. From the machine Line_up fourth is to seen entities Nr. 3 and 4, from these entities were 3 errors. The simulation can be changed to a percentage of rejected setting transitoriness of $80 \%$ and $20 \%$ will rejected up to $99 \%$ where the rate is $1 \%$ of rejected.

\section{Conclusion}

The principle of line production is in today's modern and extremely rapid time used in most businesses, regardless of orientation. In this article we describe the main problems that arise in planning and management of such production. We have also compared different heuristic methods that are used for production scheduling, and we recommend the most appropriate method in our specified case. At the end of the article, we propose a unique graphical algorithm that describes 
the steps and options in the case managing the line production. It can be used for research and educational purposes. This algorithm will be enriched in next publications for more options and choices.

\section{References}

Anu, M. (1997), "Introduction to Modeling and Simulation", Proceedings of the 1997 Winter Simulation Conference.

Brucker P., (1998), "Scheduling algorithms", 2nd edition, Springer, Heidelberg.

Bucki, R., Chramcov, B. (2011), "Modelling and simulation of the order realization in the serial production system", (2011) International Journal of Mathematical Models and Methods in Applied Sciences Vol. 5(7), 2011, pp. 1233-1240.

Carlier J., Rebai I. (1996),"Two branch-and-bound algorithms for the permutation flowshop problem", European Journal of Operational Research, vol. 90, n² 2, pp. 238--251.

Dlouhý, M. (2007), "Simulace podnikových procesů", Brno : Computer Press, 201 str., ISBN 978-80-251-1649-4.

Garey M. R., Johnson DS., Sethi R. (1976),"The complexity of flow shop and job shop scheduling", Mathematics of Operations Research, vol. 29, pp. 1:117.

Gupta, J.N.D., (1971), "A Functional Heuristic Algorithm for the Flow shop Scheduling Problem", Operational Research Quarterly, Vol.22, No.1, Pages: 39-47.

Husár, J., and Lazár, I. (2011), “Moderné prístupy v plánovaní a riadení výroby", Modelování, simulace a optimalizace podnikových procesư v praxi : sborník z konference: 29. března 2011, Zlín. - Praha : ČSOP, 2011 P. 132-140. - ISBN 978-80-260-0023-5
Johnson S. M. (1954), “Optimal two- and three-stage production schedules with setup times included", Naval Research Logistics Quarterly, vol. 8, pp. 1-61.

Knapcikova, L., Lazár, I., Husár, J. (2011), “Využitie počítačovej simulácie pri výbere optimálnej metódy dočistenia" , In: ATP Journal. Č. 8 (2011), s. 38-40. - ISSN 1336-233X

Lazár, I., Husár, J. (2011), “Tvorba algoritmov Flow-shop systému pre aplikáciu vo výrobe", In: Theory of management 4 : The selected problems for the development support of management knowledge base: Scientific Papers. - Žilina : EDIS, 2011 S. 200-205. ISBN 978-80-554-0420-2.

Lenstra J. K., Kan R., and Bruker P. (1997), “Complexity of machine scheduling problems", Annals of Discrete Mathematics, vol. 1 , pp. 343-362.

Modrak V. and Moskvich V. (2011), "Impacts of RFID Implementation on Cost Structure in Networked Manufacturing", International Journal of Production Research, Available online: 19. Sep 2011.

Sule D.R. (1982), “Sequencing n Jobs on Two Machines with set up, processing and Removal Times Separated", Naval Res. Log. Quart. Vol.29, No.3, 517 - 519. 